\title{
Peru: From Exclusionary Constitutionalism to a Transformative One, Progress and Remaining Challenges
}

\author{
Marcela Huaita ${ }^{1} \&$ Andrea Choccechanca ${ }^{1}$ \\ ${ }^{1}$ Law School, Pontifical Catholic University of Peru, Lima. \\ Correspondence: Marcela Huaita, Law School, Pontifical Catholic University of Peru, Lima.
}

Received: May 6, 2021

Accepted: May 20, 2021

Online Published: June 8, 2021

doi:10.11114/ijlpa.v4i2.5231

URL: https://doi.org/10.11114/ijlpa.v4i2.5231

\begin{abstract}
This article covers the evolution of key gender relations issues in Peruvian constitutions for almost a century, from 1931 to 2021. It analyses the path travelled from the exclusion of women as citizens to the achievement of parity in political participation; the transformation of the equality clause into one that has the possibility to incorporate discrimination based on sexual orientation as a prohibited category; as well as changes in the conception of maternity protection by the State, until one arrives at a provision that recognizes the right of people to decide individually about their reproductive choices. The article also reports on the participation of women in the struggle for these gains, their initiatives both in formal and informal spaces, as well as the demands of first and second wave feminist movements. All these points are organised through categories coined by Ruth Rubio Marín, to understand constitutionalism from a gender perspective: exclusionary, inclusive, participatory, and transformative constitutionalism.
\end{abstract}

Keywords: constitutionalism, gender, women's rights, the right to vote, equality, maternity, sexual and reproductive rights

\section{Constitutionalism and Gender}

Different authors have analysed the relationship between constitutionalism and the recognition of women's rights, but one must keep in mind that constitutional processes -in the Western tradition- have responded to the need to determine and perpetuate the structures of power distribution. This follows an anthropocentric vision and has essentially white men from intellectual elites as examples. As such, the origin of the constitutions can be identified as a masculine and liberal creation, where women historically did not have a central role (Mackinon 2012 \& Bucheli 2014).

Despite this, women have not been on the sidelines of these processes, and they have made their presence felt with different approaches. We can trace the contributions of women from the social movements that created the founding documents of modern democracies, such as the case of Olympia de Gouges (1791) or the women of Seneca Falls (1848), but whose proposals were left out of the declarations of rights created at that time. Nevertheless, in more modern processes, women fought to be incorporated into formal discussions and managed to be part of the official discussion stages of constitutional charters or the documents recognizing fundamental rights. It is there we see examples of the women of the suffrage movement such as Clara Campoamor (Deputy, Spain 1931), and Eleanor Roosevelt and her participation in the 1948 Declaration of Human Rights.

In Latin America in general, and in Peru in particular, these processes have been studied throughout the twentieth century, recognizing the importance of women's participation on two fronts: on one side, as part of civil society mobilizations in informal spaces and separate from constituent assemblies, and on the other, as actors in the official bodies responsible for drafting constitutions or bills of rights.

On each of these fronts, a series of problems can be identified that women must face in order to be part of the constitutional processes, such as: lack of information, illiteracy, the geographic centralization of processes, as well as inexperience in organization, difficulties in mobilization due to being time poor, as well as their limited ability to achieve influence in the absence of alliances and consensus-building, among other serious difficulties. Despite this, and thanks to their tenacity, women have managed to become part of formal bodies even though these spaces are intimidating and potentially hostile. Furthermore, they are often far from their social networks, and even accused of treachery when they fail to achieve their demands, either due to lack of knowledge of how to play the game, or because they have been isolated in the spheres of power. In this process, there have undoubtedly been many lessons learnt, and women politicians have managed to generate powerful alliances, succeeding in achieving important consensus and significant accomplishments throughout the region 
(Rubio, 2020).

In light of this historical process, constitutionalism can no longer forgo a gender approach. It allows us to illuminate how the rights of women, who represent approximately fifty percent of humanity, have been taking shape to produce new and more robust legal frameworks. Along these lines, Professor Ruth Rubio Marín has been developing a solid theoretical framework for understanding the history of constitutionalism from a gendered perspective (Rubio, 2015, 2020, 2021). Rubio (2021) conceptualizes four types or ways of understanding the relationship between constitutionalism and gender, these types are not necessarily mutually exclusive, that is, they are not stages that replace each other, but rather we can recognize elements of each of these expressions in national processes, namely:

- Exclusionary constitutionalism: denies women the claim to equal rights, based on the understanding that domesticity and motherhood are women's exclusive roles;

- Inclusive constitutionalism: although concerned with equality, it aspires to perfect gender neutrality in the law;

- Participatory constitutionalism: receptive to women's aspirations for participation, facilitating mechanisms for their effective participation in constitutional processes, or developing affirmative actions, such as the establishment of quotas, alternation or parity proposals;

- Transformative constitutionalism: this is focused on social reproduction and a family structure that allows the expression of diverse feminist and queer claims;

Our proposal is based on these approaches and we will analyse the Peruvian constitutions of 1933, 1979 and the current one of 1993, including its modifications.

\section{The Peruvian Constitution: Changes and Continuity}

\subsection{Exclusionary Approach: The Struggle for Women's Suffrage}

According to Rubio Marín's (2021) classification of constitutional systems proposed from a gender perspective, exclusionary constitutionalism denied equal rights to women. It is based on the understanding that the role of women is fundamentally one of domesticity and maternity, and that this is their essential and unique contribution to society. In other words, the role of women was confined to the private sphere, as housewives, mothers, and the people responsible for looking after the home and the members of the family unit. All of this did not seem to grant them space to exercise their rights of citizenship, specifically the right to vote.

Thus, the struggle for the right to vote was a major opening for women into the public sphere, although it did not necessarily involve the breaking down of traditional roles. It was more a matter of seeking equal rights in terms of democratic representation. In Peru, the struggle for women's suffrage enabled women to gradually enter the political arena, first with educated women having the right to vote in municipal elections, and then later in general elections and the right to vote for illiterate women.

The recognition of women's right to vote, at the constitutional level, was not a spontaneous process; it was the result of advocacy carried out by organizations led by women, which is why it is important to remember their quest before, during and after the constitutional processes.

At the beginning of the 20th century, one of the first socialist women, María Jesús Alvarado Rivera, formed the Consejo Nacional de Mujeres del Perú (National Council of Peruvian Women) in 1923 which was affiliated to the Consejo Internacional de Mujeres (International Council of Women) (Paris, 1888), whose main objective was the recognition of women's right to suffrage (MIMDES, 2009, p. 29). Another pioneer was Zoila Aurora Cáceres, who in 1924, founded the Asociación Feminismo Peruano (Peruvian Feminist Association). Through the association, she made public her manifesto in favour of suffrage on the election day for the Constituent Congress of 1931 (MIMDES, 2009, p. 31). That same year, due to the pressure exerted by women to intervene in the political elections, the voting rights act included the clarification "that Peruvian men who could read and write and who were fully permitted to exercise their civil rights, were obliged to enrol in the National Electoral Register" (Aguilar, 2002, p. 125). This clarification left women out of the electoral process.

In light of this background, women's right to vote was one of the topics to be discussed in the Constituent Congress of 1931-1932, which was made up of 145 male delegates. Congress was mainly composed of the Partido Unión Revolucionaria (Revolutionary Union Party), followed by the partidos Alianza Popular Revolucionaria Americana (Popular American Revolutionary Alliance, APRA for its acronym in Spanish), the Partido Descentralista del Perú (Decentralist Party of Peru), the Partido Socialista del Perú (Socialist Party of Peru) and independents. They had three different positions on the debate about women's suffrage: "the delegates of the Decentralist Party of Peru were the most outspoken against women's suffrage; APRA's members as a party defended qualified or restricted suffrage; and many supporters of the government or the Revolutionary Union defended unrestricted or large-scale voting for women" (Aguilar, 2002, p. 129). 
In general, the majority of the delegates were concerned that women would leave and neglect the domestic sphere to which they had been relegated, especially because they were not sure how women's entry into the political scene would have an impact on them. Despite proposals with conditions for exercising the right to vote such as education and work, it was not possible to find a consensus. However, at the initiative of Congressman M. Arébalo of the Revolutionary Union Party, a conciliatory alternative was proposed which consisted of granting women the voluntary vote in municipal elections. The argument against the above proposal was that "the female population was superior to the male population and to grant them the right to vote would be to create a privilege for women to the detriment of men" (Aguilar, 2002, p. 154). Similarly, the decentralist congressmen, who in principle were opposed to women's right, accepted the proposal because "the municipal vote and the political vote were on different levels; as the municipalities were close to the community life, the unrestricted vote was applicable to women" (Aguilar, 2002, p. 154). So finally, in the 1933 Constitution, women's right to vote in municipal elections was recognized in Article 86, under the following terms: "Citizens who know how to read and write can enjoy the right of suffrage; and Peruvian women of legal age [21 years old] in municipal elections who are married or who have been married, and mothers of families even if they have not reached adulthood". In practice, this right to vote was not exercised until 1963 due to Peru's turbulent political scene, the 1933 Constitution was suspended and municipal elections were not scheduled until the 1960s.

Continuing with the history of the struggle for women's right to vote, between 1941 and 1954 different unsuccessful initiatives were launched, mostly promoted by women's organizations such as el Comité Nacional Pro Derecho Civiles y Políticos de la Mujer (the National Committee for Women's Civil and Political Rights), la Asamblea de Evolución Femenina (the Assembly of Women's Progress), la Asociación Femenina Universitaria (the Feminist University Association), and la Asociación de Abogadas Trujillanas (the Association of Women Lawyers of Trujillo) (MIMDES, 2009, p. 36-37). In response to the numerous demands of women, on September 5, 1955, the government of Manuel A. Odría enacted Law 12391, which modified the 1933 Constitution and granted the right to vote to women over 21 years of age who could read and write, and to married women over 18 years of age with the same conditions (MIMDES, 2009, p. 38). Through this law, the recognition of women's citizenship was achieved and, for the first time, on June 17, 1956, they participated in the general election. Although legally speaking, women were citizens, their participation in political activity took place gradually and with certain difficulties, since prejudices and stereotypes that confined them to the domestic sphere still prevailed.

Although this step was an important achievement, it was still not enough to say that all women were on equal footing with men. Voting was only exercised by literate men and women, and at that time women accounted for the vast majority of the illiteracy rate. This was due to women's role being relegated to the domestic sphere which meant they did not have opportunities to access education.

In the Constituent Assembly (AC for its acronym in Spanish) of 1978-1979, the need to identify and register illiterate people was raised, and, throughout the debate, the assembly members brought up the possibility of granting them the right to vote. There was favourable discussion based on the fact that men are equal by nature and that being illiterate does not constitute inferiority or a lesser status. Furthermore, it was highlighted that illiteracy was most widespread in small-scale farmers. Only one assemblyman, Javier Diez Canseco, made reference to the gender issue, stating that according to the 1972 census, $28 \%$ of the population was illiterate and more than $70 \%$ of them were poor women (AC, 1978, Volume III, p. 225). In light of this, Article 65 of the 1979 Constitution was approved with the following wording: "Peruvians over eighteen years of age are citizens. In order to exercise citizenship, registration in the Electoral Register is required. All citizens who are able to exercise their civic capacity have the right to vote. (...)".

Thus, the enshrining of universal suffrage in the 1979 Constitution was very important since it meant progress in the process of democratization of the public sphere. As will be seen later, women do not limit themselves to only exercising their right to vote but are increasingly interested in participating in the political arena.

\subsection{Inclusive Approach: Changes in the Equality Clause}

Following the theoretical theme of the author Rubio Marín (2021), inclusive constitutionalism consists of perfect legal neutrality in the law in terms of gender, which means not obstructing women with legal barriers. The author explains this theory, mainly from what she has called assimilationist workerism, contextualized in the United States in the 1970s. This theory states that the norms, instead of reflecting and accommodating the real functional differences between the sexes, should ignore them in order to free the individual from the expectations that may be imposed upon him/her (Rubio, 2015, p. 797); that is, it forces women to adapt to the male standard instead of observing their specific female needs, which may put conditions on the right to equality. In this sense, the limitations of the law are uncovered since it does not contemplate protection for either pregnancy or maternity.

Notwithstanding the above, the author considers that there is a different way of understanding inclusive constitutionalism, through the theory of accommodationist workerism, contextualized in Europe in the 1960s and 1970s. It consists of 
seeking "the adoption of measures to facilitate the combination of paid employment and unpaid care labor, but mostly for women, thereby accommodating and entrenching, rather than ignoring or subverting, women's unique role in reproduction and family sustenance as well as generalized gender stereotypes surrounding it" (Rubio, 2015, p. 800). This indicates that the law should be clear and specific when referring to the special situations in which a woman finds herself due to her status as a woman, in order not to leave her legally outside the framework of equality before the law.

In Peru, the right to formal equality for women has been present in the debates of the constitutional processes, with the exception of the Constituent Congress of 1931-1932, since the main topic of this assembly was the right to vote. However, as previously stated, the main argument for not granting such right was precisely that men and women are not equal, since each has its role, assigned by nature, within the social order.

The issue of equality was formally promoted within the State, during the government of Juan Velasco Alvarado, who in August 1974, approved the Inca Plan. One of the plan's objectives was "to achieve true equality with men in rights and obligations, through actions such as the elimination of all discriminatory treatment that limits women's opportunities and affects their rights and personal dignity, the promotion of their effective participation in all social activities and responsibilities at all levels of decision making in the country" (Barboza, 2013, p. 70).

The clause of equality before the law was debated for the first time in the Constituent Assembly of 1978-1979 with the following wording: "Everyone has the right: to equality before the law, without any discrimination based on race, sex, religion, opinion and language. Men and women have equal rights, opportunities, and responsibilities. Any act that impedes this must be eliminated". In principle, the proposed legal text fits into the theory of assimilationist workerism, since it obliged women to assume rights, opportunities, and responsibilities that men already enjoyed.

However, delegate Cornejo Chávez questioned the text, stating that in labour law there were provisions established according to sex, so much so that women have certain rights that men cannot have for biological reasons. Therefore, if it were flatly stated that there is no discrimination based on sex, it could lead to erroneous interpretations to the detriment of women, such as denying women workers the rights corresponding to pregnancy and childbirth (AC, 1978, Volume V, p. 533). This criticism is compatible with the theory of accommodationist workerism, since it is based on the recognition of women's role as mothers to justify the adoption of measures to promote a balance between paid and unpaid work. However, the proposal to eliminate the category "sex" is striking, since, contrary to what it claims, it makes certain types of discrimination more visible. However, the final text of the 1979 Charter did consider this category in addition to the proposal of delegate Cornejo Chávez, and the constitutional text was worded as follows: "Article 2.-Every person has the right: (...) 2. To equality before the law, without any discrimination based on sex, race, religion, opinion, and language. Men and women have equal opportunities and responsibilities. The law recognizes the rights of women no less than those of men. (...)".

In the Democratic Constituent Congress (CCD for its acronym in Spanish) of 1993, the equality clause was widely discussed. The proposal was presented by the partido Cambio 90 (Change 90 party or C90 party), which had congressional majority, with the following wording: "Every person has the right: 2 . To equality before the law. No one shall be discriminated against based on origin, race, sex, religion, opinion, language, economic level or any other reason". We can see here that the elimination of the second paragraph is proposed, which contains the equivalent article of the 1979 Constitution: "Men and women have equal opportunities and responsibilities. The law recognizes the rights of women no less than those of men". Delegate Torres y Torres Lara, on behalf of the C90 party, based this elimination on the fact that having recognized equality before the law, it is redundant to specify equality of opportunities and responsibilities. He also stated that the last sentence created confusion regarding, for example, the protection of maternity in the labour sphere, since it could be interpreted as greater rights and not as natural rights pertaining to women because of their status (CCD, 1993, Volume I, p. 70).

In response to this, Congresswoman Lourdes Flores Nano of the Partido Popular Cristiano (Popular Christian Party, PPC for its acronym in Spanish) reaffirmed the value of the second paragraph, which through recognition and modifications led to changes being implemented that contributed to equality between women and men. Furthermore, due to the educational indices of women and men, unemployment and underemployment affect women to a greater extent, which is why it is still necessary to establish laws that contemplate "active discrimination". Finally, regarding the last sentence of the paragraph, the congresswomen maintained that these are not greater rights, but differentiated rights that are granted to women due to their sex (CCD, 1993, Volume I, p. 71-72).

After long speeches in favour of the proposal from the majority, and the lack of support for the proposal to maintain the second paragraph of article 2, subsection 2 of the 1979 Constitution, the following text was approved: "Everyone has the right: 2 . No one shall be discriminated against on the grounds of origin, race, sex, language, religion, opinion, economic level or any other reason". This establishes the neutrality of equality before the law, as referred to in the theory of assimilationist workerism. 
A relevant issue is that the legal clause, by stating that no one should be discriminated against for "any other reason", has the potential to introduce other types of discrimination, such as for reasons of sexual orientation or gender identity. This was subsequently interpreted in the ruling of a case in which recognition of same-sex marriage was being discussed by the judges Ledesma and Ramos, in their dissenting opinion, which in its 46th section reads as follows:

"(...) when interpreting the principle right to equality and non-discrimination recognised in Article 2, paragraph 2, of the Constitution, in conjunction with Article 37, paragraph 1, of the Constitutional Procedural Code, allowing us to arrive, once again, at the conclusion that non-heterosexual sexual orientation cannot, in any case, be a reason for discrimination through any norm or act, whether it comes from a public authority or from private individuals". (Constitutional Court, Judgment 676/2020, 2020)

\subsection{Participatory Approach: Progress in the Equal Participation of Women}

In the struggle for progress with women's rights, the importance and necessity of women's participation in decisionmaking spaces stands out. The author Ruth Rubio Marín calls this participatory constitutionalism, which consists of giving ordinary citizens the opportunity to take part in spaces for discussion and to decide directly on the constitution, in such a way that new ways are opened up for constitutional inclusion of historically silenced sectors of the population, including women (2020, p. 45-46).

As we have seen above, in a little less than a century, Peruvian women have gone from not being recognised as citizens by the state to fighting for parity in representative positions at regional and national levels. This history is also riddled by rallies and disagreements in both formal and informal spaces, where women and their organisations have struggled to widen the extent of their participation.

This knowledge allows us to understand what happened in the Constituent Congress of 1931-1932; Magda Portal, a historic leader from the APRA, saw how her party did not defend the demands for universal suffrage for women aged 18 and over put forward by her and other women in her party, but rather supported opposing positions in the Constituent Congress of 1931-1932, as we have analysed above. Portal ended up resigning from the party in 1948, given that, in accordance with the aforementioned constitution, women were not recognised as active members of the party because they were not citizens (Bermúdez, 2018, p. 117).

Throughout the 1940s, as we have seen above, women continued to fight through various organisations and movements for recognition of their right to vote. This shows that women never stopped fighting until they achieved this recognition in 1955, with the right to vote only for educated women, and later, in the 1979 Constitution, with universal suffrage.

A few decades later, the second wave of feminism arrived in Peru, giving rise to different processes which manifested themselves with significant force throughout the 1970s. It was in that decade that a certain crossroads was observed between the agenda of the state, in the grip of a military dictatorship, and the positioning of women in the public sphere, which somehow channelled a response to the women's movement's demand for public participation (Barrientos \& Muñoz, 2014, p. 640). At the end of the decade, there was a process of democratic opening that led to the convening of a Constituent Assembly (1978-1979), in which two women were elected, one left wing: Magdalena Benavides for the Frente Obrero Campesino Estudiantil y Popular (Workers, Farmers, Students and People's Front, FOCEP for its acronym in Spanish), and another right wing: Gabriela Porto de Power of the Partido Popular Cristiano (Popular Christian Party, PPC for its acronym in Spanish). Coincidentally, at the same time, two important feminist organisations were also founded in Peru: the Manuela Ramos Movement (1978), and the Flora Tristán Centre (1979), with the most prominent figures going on to develop a political presence in the following decade and become candidates for Congress in the 1985 elections. However, the experience was hard and in the words of its protagonists: "We learned in a brutal way that political parties were not our space (...) and, if we wanted to extend the impact of feminist ideas on women and society, this would only be possible by taking on the struggle to expand democracy as a way of life and not just as a form of government" (Vargas, 2016, p. 72).

The following decade in Peru was a difficult one due to terrorism and the economic crisis and it led to the new Constitution of 1993, which chiefly sought to change the economic model. Thirteen of the 120 members of Congress were women with seven from the governing party, making this the largest number of women ever to participate in a constituent assembly in Peru.

It is under this current Constitution that the feminist movement achieved a significant increase in women's political participation through affirmative mechanisms such as quotas, alternation, and parity. However, at the beginning, when the approval of this constitution was submitted to a referendum, the feminist movement launched a campaign for a NO vote, under the slogan: "A constitution that is not good for women is not a good constitution" (José, 2006, p. 114). This was due to the changes in the equality clause, among others, advocated in the previously analysed CCD of 1993.

Affirmative action mechanisms, such as quotas, had been put on the public agenda in the early 1990s by the feminist 
coalition Foromujer (Bermudez, 2018, p. 143). However, this only increased momentum in the formal sphere when congresswomen attended the World Conference on Women in Beijing (1995), and since then, in the first two decades of the $21^{\text {st }}$ century it has continued to expand and gain legitimacy. The need to adopt affirmative action in the electoral legal system has been an intense demand by female politicians from different political groups since 1996, going from an official quota of $25 \%$ for general elections (Law 26859, 1997) to a quota of $30 \%$ (Law 27387, 2000). These achievements were important precedents for the 2002 constitutional reform to include the need for "gender representation" in regional and municipal councils, which was incorporated into the constitutional text through the reform of the chapter on decentralisation (Law 27680, 2002). Nonetheless, this provision was not exempt from criticism and efforts to change it, which is why female politicians from different political groups had to defend it, for example in 2005 when an attempt was made to modify it (Bermudez, 2018, p. 156).

This constitutional provision enabled the demand for greater female participation to continue expanding, but the defence of this provision also proved to be a platform on which not only women from different political groups could align themselves, but also the organisations of the feminist movement. Thus, in the 2011-2016 legislative period, up to nine bills were presented proposing alternation, including one promoted by the executive branch itself, in which government measures for the advancement of women played a relevant role (MIMP, 2013). In the following legislative period, 20162021 , the demand was extended not only to alternation but also to parity, aligning this time not only female politicians, but also the electoral body itself (Jurado Nacional de Elecciones). This was supported by the collective feminist movement group "We are half of the people, we want parity", a collective that brings together -among other organisations- those founded at the end of the 1970s and previously mentioned in this text. This led to the approval of Law 31030 (2020), the first application of which took place in the April 2021 elections, ushering in a new era in terms of women's political participation.

\subsection{Transformative Approach: The Centrality of Social Reproduction and a Family Structure That Challenges Traditional Relationships}

The process known as transformative constitutionalism establishes that constitutional law itself is the mechanism for transforming the gender order which it historically helped to establish (Rubio, 2021). This implies questioning the gender roles that marked the boundary of the public sphere from the private sphere, and consequently places demands related to maternity, marriage and common-law marriage, gender violence, responsible parenthood, sexual and reproductive rights, among others on the government's agenda.

In Peru, maternity is declared under the protection of the State from the 1933 Constitution to the 1993 Constitution. However, it is interesting to distinguish the nuances that occur from one constitution to another when comparing the different constitutional provisions, until one arrives at a provision that protects the decision of each person individually and without discrimination on whether or not to have children, as well as access to information and the appropriate means to do so.

The 1933 Constitution, which represents a very traditional view of society, mentions three different but somehow related institutions: the family, marriage, and maternity, establishing that all of them deserve the state's legal protection. Although it does not sanction other family forms, this legal provision seems to be in tune with what was established in civil legislation of that time (Civil Code of 1852 and 1936), where illegitimate children have a different status to those born within a married family.

Women who have children are the subject of concern in the 1979 and 1993 Constitutions, in two cases: when they are in a situation of family abandonment or insufficient support, and when they are working mothers. Thus, in the 1979 Constitution, although maternity in general terms continues to be protected by the State, it is emphasised that mothers will only benefit from assistance in cases of abandonment (Article 7). In the 1993 Constitution, the focus of protection was changed, and it is no longer placed on maternity per se, rather it was set out that the state's special protection should be given to people in situations of abandonment, among them mothers, but also children, adolescents, and the elderly. This last provision, then, ceases to deem women vulnerable because of their maternity, and establishes other criteria such as the situation of abandonment in which they may find themselves.

Another area that has undergone one of the greatest changes, is labour rights. In the 1979 Constitution, one chapter was dedicated to it, but this chapter disappeared in the 1993 Constitution, and its regulations are summarised and integrated into a chapter generically dedicated to social and economic rights. In relation to working mothers, the 79 Charter establishes that "The law determines the measures to protect working mothers" (Article 45) in accordance with the provisions of the previously analysed article, which recognised "rights no less than those of men", and precisely in the area of employment, that women can grow autonomously. For its part, the Charter of 1993 also establishes that the State protects "mothers especially"; however, this duty is equated to that which corresponds to the State in relation to "minors" and "handicapped", and therefore it would seem that protection is in the sense that they are a "vulnerable population". 
This is in line with what we have mentioned above and does not emphasise the special conditions for which women may merit protection in the labour sphere.

Another area of interest is the change in the status of marriage. As early as 1931, Peru had already passed a law on civil marriage (Decree-Law 7282, 1931), making it independent of religious marriage and the only one recognised as having valid legal effects, and therefore the "protection of the law". This protection left out cohabiting couples, who were found all over the country, especially in the poorest areas. Thus, in 1961, in the Law of Shanty Towns or Disadvantaged Neighbourhoods (Law 13157, 1961), it was established that in the case of cohabiting couples that do not have impediments to marry, the title deed would be issued with both their names. Something similar occurs with the Law of Agrarian Reform (Decree-Law 17716, 1969), which sees the need to recognise the right of the common-law wife in the event of a partner's death. These, then, are the main precedents for the 1979 Constitution to recognise the legal status of common-law unions, as long as they are between a man and a woman, free of matrimonial impediment and with a purpose similar to marriage. This provision was also included in the 1993 Constitution, recognising that constitutionally including this institution is especially important for women, as expressed by Congressman García Mundaca: "Who was harmed by not recognising cohabitation, which is such a common institution among Peruvians? women and children; very unlikely men. (...)" (CCD, 1993, Volume I, p. 81).

However, the 1993 Constitution would establish a subtlety in relation to the role of the State, in the sense that although it is the State's duty to protect the family -whatever its origin- with respect to marriage, its duty will be to promote it. Congressman Cáceres Velásquez stated that the idea of "'promotion' means that the State will be interested in the regularisation of irregular unions, that marriage will happen, that unions will be formalised (...)" (CCD, 1993, Volume I, p. 81). It would seem then that although there is an extension of state protection to all forms of families, the Politicians in 1993 wanted to make it clear that marriage is the institution through which the state will provide greater security. However, in practice, married women could be more vulnerable than cohabiting women to situations such as spousal violence, since, for example, married women could not denounce their husbands for rape until 1997 (Law 26770). Despite the declaration of the 1993 charter, national legislation has been making rights of heterosexual cohabiting couples more equal, even recognising inheritance rights (Law 30007, 2013).

Another very sensitive issue for the feminist movement was domestic violence, an issue that has not been recognised in any constitution. Despite being formally proposed in the 1993 constitution by some congresswomen such as Lourdes Flores Nano and Luz Salgado Rubianes, who unsuccessfully proposed giving protection against domestic violence constitutional status so that it could then be regulated by law; Flores Nano stated: "We therefore propose a third paragraph of this article which refers to the family, with the regulation stating: "The law establishes mechanisms for protection against domestic violence", an area which can then be developed at a legal level" (CCD, 1993, Volume I, pp. 357-358).

Finally, it was the 1979 Charter that introduced for the first time a constitutional provision on "responsible parenthood", i.e., on the thorny issue of reproductive rights. However, according to what assemblywoman Porto de Power said, the provision seemed to have more to do with avoiding mothers being abandoned by their partners than with the decision of whether or not to have children, the information and means to access it. The previously mentioned assemblywoman therefore stated:

"(...) I would like to draw attention to article 3, which declares that the State protects responsible parenthood, since we are facing the social problem of family abandonment on a grand scale. The Courts of Justice are overwhelmed by these cases, which are becoming more and more numerous and traumatic, to the detriment of children. Abandoned mothers are forced to demand the right that their children's fathers feed and educate them". (AC, 1978, Volume VI, pp. 15 - 16).

A different situation arose in the $1993 \mathrm{CCD}$, where the debate revolved around population policy and access to contraceptive methods. This is corroborated by the positions expressed, such as that of delegate Tudela Van BreugelDouglas, who expressed his reservation because "Responsible parenthood (...) is a matter left to the minds of individuals and cannot be established as a constitutional norm" (CCD, 1993, Volume I, p. 363). Further positions were expressed by others, from a conservative position, that although families could make these decisions, they warned of the risk that the approval of this constitutional article could entail for women, as delegate Rey Rey maintains:

"I publicly accuse the current Health Minister of this government of attacking the health of thousands, probably millions of women in our country, because he is disseminating, distributing and authorising the sale of many contraceptive products which are not only medically proven to be abortifacients -which is therefore clearly classed as an offence in our legal system- but also because many of these medical products have serious side effects on women's health" (CCD, 1993, Volume III, p. 2113).

More liberal voices, both women and men, such as Lourdes Flores Nano and Julio Castro Gómez, are also identified, emphasising the decision of couples, as well as the position of the government of the day, as expressed by Congressman Freundt-Thurne Oyanguren of the C90 party: 
"(...) We believe that responsible parenthood is one of the cornerstones of any country that wants to move forward. (...) With this wording of Article 7, we are trying to define, by constitutional means, the objectives of responsible parenthood which allow the free decision of individuals to use the method they consider most appropriate, as long as it does not go against anyone's life". (CCD, 1993, Volume III, p. 2110).

At this point in the debate, it seems that the provision under discussion takes little account of women's voices and more a vision of a population policy promoted by the government of the day, and whose constitutional consolidation was key to the public policy decisions that followed in the 1990s (Rousseau, 2007). This led to the drafting of the constitutional text as follows:

"Article 6. National Population Policy. Responsible parenthood. Equality of children. The National Population Policy aims to disseminate and promote responsible parenthood. It recognises the right of families and individuals to decide. In this regard, the State ensures adequate education programmes, information and access to it, that do not affect health or lives. (...)" (Constitution, 1993).

At this point, it is interesting to emphasise that the proposed provision, brings with it an element of great potential, such as the recognition of the right of individuals to their reproductive freedom, which in itself is revolutionary. It also establishes the obligation of the State to ensure the means to do so, thus opening a new chapter in Peruvian constitutional history. This, coupled with a broad interpretation of the previously discussed equality clause to include sexual orientation as a prohibited category of discrimination, may give rise to truly transformative constitutional progress.

\section{Challenges on the Eve of a New Centenary}

Fighting for women's rights has been and still is, without a doubt, an arduous task, as it implies challenging the gender order imposed by society and the law, in which women are at a disadvantage when compared to men. It was only thanks to women's organisation that our demands were debated in the constituent assemblies. This is how we went from gaining the right to vote to achieving protection and the promotion of other rights derived from our status as citizens.

Each constitutional process from 1931 to 1993 allowed us to learn about and discuss women's demands. Seen from the theory of constitutionalism with a gender lens, we began with an exclusionary constitutionalism that denied women's equality, arguing that by nature, we were only destined to carry out domestic work and be mothers. Therefore, obtaining the right to vote was an initial opening into the public and political sphere, as it meant recognising women as citizens. However, in the first discussions held in the 1931-1932 assembly, only the municipal vote was recognised and not full citizenship; later, in 1955, the right to vote was recognised only for educated women; the real victory would come with the 1979 Constitution, which recognised universal suffrage.

In the midst of this process, the right to equality before the law was also discussed, as the recognition of women's citizenship meant placing them on equal footing with men; consequently, a clause on equality before the law within the framework of inclusive constitutionalism, was included for the first time. This allowed society and especially women, to become aware of their rights, to move their demands from the private/domestic sphere to the public/political sphere, either through organisations or through representation by politicians in constituent assemblies; this has been called a process of participatory constitutionalism. The demands dealt with issues such as maternity, responsible parenthood, domestic violence, sexual and reproductive rights, the status of marriage and cohabitation, among others, which prompted the questioning and transformation, to some extent, of traditional gender roles. This can be seen from the process of transformative constitutionalism.

The historical review of women's rights' victories leads us to multiple reflections, among them the need to continue challenging the gender order. Despite having managed to leave the confinement of the private sphere, we are still obliged to maintain the household through domestic work, care for family members and be mothers, as well as experiencing violent relationships and discrimination. However, going out into the public sphere has not guaranteed respect for our rights as power relations and violence are prevalent despite progress. Hence the need to continue with the transformative process that truly addresses the unresolved gender demands.

We believe that, on the eve of a new centenary, we still need to discuss equality and non-discrimination rights, because despite having a general equality clause, it is necessary to enshrine non-discrimination based on sexual orientation and gender identity at the constitutional level, as well as the right to a life free of gender-based violence. Furthermore, although we have witnessed an increase in women's participation in representative positions, it is still urgent to guarantee and promote affirmative action to ensure that such participation is effective. Finally, demands that have been constantly occurring in feminist movements are relevant, such as the recognition of same-sex unions (marital and non-marital), recognition of equal rights and responsibilities in relation to the family, and guaranteeing true sexual and reproductive autonomy for women. We consider that in the face of a possible new constitutional process in Peru, all these demands should be included in the discussions that are put forth, as well as in the constitutional text. 


\section{References}

Aguilar, R. (2002). El sufragio de la mujer: Debate en el Congreso Constituyente de 1931 - 1932. Elecciones, 1, 123-164.

Asamblea Constituyente - AC. (1978). Diario de los debates de la Asamblea Constituyente 1978 (Tomos III, V y VI). Lima, Perú. Retrieved from http://www4.congreso.gob.pe/dgp/constitucion/1979/const1979nivel2-a-ii.htm

Barboza, M. L. (2013). La liberación de la mujer en el Perú de los 70's: una perspectiva de género y estado [Tesis de maestría, Universidad Nacional Mayor de San Marcos].

Barrientos, V., \& Muñoz, F. (2014). Un bosquejo del feminismo/s peruano/s: los múltiples desafíos. Revista Estudios Feministas, 22(2), 637-645. https://doi.org/10.1590/S0104-026X2014000200015

Bermúdez, V. (2018). La paridad como medida necesaria para la participación política de las mujeres en condiciones de igualdad [Tesis de maestría, Pontificia Universidad Católica del Perú].

Buchely, L. F. (2014). Género y constitucionalismo. Una Mirada feminista al derecho constitucional colombiano. Ciencia Política, 9(18), 83-107.

Congreso Constituyente Democrático-CCD. (1993). Debate Constitucional Pleno 1993 (Tomos I y III). Lima, Perú.

José, M. (2006). Nuevas Constituciones para todos y todas. En S. Montaño y V. Aranda, Reformas constitucionales y equidad de género (pp. 89-133). CEPAL, Unidad Mujer y Desarrollo. Retrieved from https://www.cepal.org/sites/default/files/publication/files/6827/S0500089_es.pdf

Mackinnon, C. A. (2012). Foreword. En B. Baines, D. Barak-Erez \& T. Kahana (Eds.), Feminist Constitutionalism-Global Perspectives. Cambridge University Press, ix-xii. https://doi.org/10.1017/CBO9780511980442.001

Ministerio de la Mujer y Desarrollo Social - MIMDES. (2009). 50 años del Voto Femenino en el Perú: Historia y Realidad Actual.

Ministerio de la Mujer y Poblaciones Vulnerables - MIMP. (2013). Alternancia de Género. Realidades y desafíos de la participación política de las mujeres. Retrieved from https://www2.congreso.gob.pe/sicr/cendocbib/con4_uibd.nsf/F346837707EE2FA605257DFF00513849/\$FILE/Alt ernancia_Porlaigualdad.pdf

Rousseau, S. (2007). Las Políticas de Salud Reproductiva en el Perú: Reformas Sociales y Derechos Ciudadanos. Estudios Feministas, 15, 309-331. https://doi.org/10.1590/S0104-026X2007000200003

Rubio, R. (2015). The (dis)establishment of gender: Care and gender roles in the family as a constitutional matter. International Journal of Constitucional Law, 13, 787-818. https://doi.org/10.1093/icon/mov059

Rubio, R. (2020). Mujeres y procesos constituyentes contemporáneos: retos y estrategias de participación. Revista de Estudios Politicos, 187, 43-69. https://doi.org/10.18042/cepc/rep.187.02

Rubio, R. (2021). Observatorio Internacional de Derechos Humanos - I Jornada Ruth Bader Ginsburg: la voz de la justicia [Seminario Web]. Academia Interamericana de Derechos Humanos. Retrieved from https://www.facebook.com/AcademiaIDH/videos/326195468753615

Sentencia 676/2020. (2020). Tribunal Constitucional (Voto singular de los magistrados Ledesma Narváez y Ramos Núñez). Retrieved from https://tc.gob.pe/jurisprudencia/2020/01739-2018-AA.pdf

Vargas, V. (2016). Los feminismos en el laberinto de las izquierdas gobernantes en América Latina. Reflexiones inacabadas. Revista de Sociología, 26, 69-86. https://doi.org/10.15381/rsoc.v0i26.18985

\section{Copyrights}

Copyright for this article is retained by the author(s), with first publication rights granted to the journal.

This is an open-access article distributed under the terms and conditions of the Creative Commons Attribution license which permits unrestricted use, distribution, and reproduction in any medium, provided the original work is properly cited. 